\title{
Acaricidal and oviposition deterring effects of santalol identified in sandalwood oil against two-spotted spider mite, Tetranychus urticae Koch (Acari: Tetranychidae)
}

\author{
Hyun Sik Roh $\cdot$ Eu Gene Lim · Jinwoo Kim • \\ Chung Gyoo Park
}

Received: 31 March 2011/ Accepted: 12 July 2011 / Published online: 26 July 2011

(C) The Author(s) 2011. This article is published with open access at Springerlink.com

\begin{abstract}
Thirty-four plant essential oils were screened for their acaricidal and oviposition deterrent activities against two-spotted spider mite (TSSM), Tetranychus urticae Koch (Acari: Tetranychidae), in the laboratory using a leaf-dip bioassay. From initial trials, sandalwood and common thyme oils were observed to be the most effective against TSSM adult females. Subsequent trials confirmed that only sandalwood oil was significantly active $(87.2 \pm 2.9 \%$ mortality) against TSSM adult females. Sandalwood oil also demonstrated oviposition deterring effects based on a $89.3 \%$ reduction of the total number of eggs on leaf disks treated with the oil. GC-MS analysis revealed that the main components of the sandalwood oil were $\alpha$-santalol (45.8\%), $\beta$-santalol (20.6\%), $\beta$-sinensal (9.4\%), and epi- $\beta$-santalol (3.3\%). A mixture of $\alpha$ - and $\beta$-santalol (51.0:22.9, respectively) produced significantly higher mortality $(85.5 \pm 2.9 \%)$ and oviposition deterrent effects $(94.7 \%$ reduction in the number of eggs) than the control. Phytotoxicity was not shown on rose shoots to which a $0.1 \%$ solution of sandalwood oil was applied.
\end{abstract}

Keywords Tetranychus urticae · Essential oil · Natural acaricide $\cdot$ Sandalwood $\cdot$ Santalol . Common thyme

Communicated by J. Gross.

H. S. Roh · E. G. Lim · J. Kim · C. G. Park $(\bowtie)$

Division of Applied Life Science (BK21 Program)/

Research Institute of Life Science,

Graduate School of Gyeongsang National University,

Jinju 660-701, Republic of Korea

e-mail: parkcg@gnu.ac.kr

\section{Introduction}

The two-spotted spider mite (TSSM), Tetranychus urticae (Acari: Tetranychidae), is a serious pest on various greenhouse vegetables and food crops (Lee et al. 2003b; Song et al. 1995; Takafuji et al. 2000). Damage by TSSM can cause direct effects including small spots on the leaf due to chlorophyll depletion, webbing, defoliation, necrosis in young leaves and stems; indirect effects including decreased photosynthesis and transpiration, and finally death of the whole plant (Badawy et al. 2010).

Control of the TSSM with conventional (chemical or non-chemical) acaricides is difficult due to its ability to rapidly develop resistance to the acaricides used (Cho et al. 1995; Song et al. 1995; Stavrinides and Hadjistylli 2009; Badawy et al. 2010). TSSM has evolved resistance to an estimated 80 or more acaricides to date (Van Pottelberge et al. 2009). Continuation of conventional acaricide use against TSSM can cause serious adverse effects against humans, the environment, and non-target organisms, including insects and predatory mites such as Phytoseiulus persimilis (Acari: Phytoseiidae) (Kumral et al. 2010). However, control of TSSM depends largely on the use of conventional acaricides. Therefore, new control technologies and relevant tactics to reduce the use of conventional pesticides are needed to achieve sustainable management of TSSM (Isman 2001; Lee et al. 2003a).

Semiochemicals are promising candidates to achieve environmentally friendly pest management. Several essential oils have toxic activities against various pests including TSSM. Many plant-derived secondary metabolites are toxic to different species of spider mites, including TSSM (Choi et al. 2004; Miresmailli et al. 2006). For example, extracts of Capparis aegyptia (Capparaceae) was toxic to TSSM females (Hussein et al. 2006). Crude extracts from 
Capsicum (Solanaceae) fruits and from subfamilies Ajugoideae, Scutellarioideae, Chloanthoideae, Viticoideae, and Nepetoideae (Lamiaceae) were repellent and toxic to TSSM (Antonious et al. 2006; Rasikari et al. 2005). Extracts of Ailanthus altissima L. leaves and Convolvulus krauseanus Regel and Schmalh roots were also found to be active against TSSM (Chermenskaya et al. 2010), while leaf and seed extracts from Datura stramonium had demonstrated acaricidal, repellent, and oviposition deterrent activities against the spider mite (Kumral et al. 2010).

The goal of this study was to find new materials for potential use in controlling TSSM. Thus, 34 commercially available plant essential oils were screened against TSSM adult female. GC-MS analysis was used to identify the main constituents of sandalwood oil, and then a mixture of two main constituents, $\alpha$ - and $\beta$-santalol, was tested for its acaricidal and oviposition deterring effects in the laboratory.

\section{Materials and methods}

Mites and plants

Acaricide-susceptible TSSM, T. urticae, was obtained from Gyeongnam Agricultural Research \& Extension Services in 2007. They were maintained in the absence of acaricides at $25 \pm 2{ }^{\circ} \mathrm{C}, 60 \pm 10 \% \mathrm{RH}$, and 16L:8D on kidney bean (Phaseolus vulgaris var. humilis) plants in the insectary at the Insect Chemical Ecology Laboratory, Gyeongsang National University, Korea. Adult females (2-3-day old) were used in laboratory bioassays to assess the adulticidal effects of the essential oils and santalol. To obtain vigorous T. urticae, fresh kidney bean plants bearing 3-4 leaves were placed between the bean plants infested with $T$. urticae for 24-48 $\mathrm{h}$. The TSSM adult females moved onto the fresh leaves and sucked plenty of fresh juice were used for experiments.

Essential oils and compounds

Thirty-four commercial plant essential oils were purchased from HerbMall Co. Ltd., (Seoul, Korea). Table 1 shows names of the essential oils used in these experiments, their extraction methods, and plant parts extracted. Santalol (a mixture of $\alpha$ - and $\beta$-santalol at 51:23 ratio) was purchased from MP Bio Inc. (Thuringer, Germany).

Laboratory bioassay of essential oils and santalol

$200 \mu \mathrm{l}$ of each essential oil or santalol was dissolved in $20 \mathrm{ml}$ ethanol (97\%, Burdik and Jackson, USA), and then
Table 1 List of commercial essential oils, their scientific name, what plant part they originated from and the method used to extract them

\begin{tabular}{|c|c|c|c|}
\hline Essential oil & Scientific name & $\begin{array}{l}\text { Plant part } \\
\text { used }\end{array}$ & $\begin{array}{l}\text { Extraction } \\
\text { method }\end{array}$ \\
\hline Bergamot & Citrus bergamia & Zest & $\mathrm{P}$ \\
\hline Bitter orange & $\begin{array}{l}\text { Citrus aurantium var. } \\
\text { armara }\end{array}$ & Bud & $\mathrm{S}$ \\
\hline Black pepper & Piper nigrum & Fruit & $S$ \\
\hline Blue gum & Eucalyptus globulus & Leaf & $S$ \\
\hline Cajeput tree & Melaleuca leucadendron & Leaf & S \\
\hline Cedarwood & Cedrus atlantica & Wood & $S$ \\
\hline Cinnamon & $\begin{array}{l}\text { Cinnamomum } \\
\text { zeylandicum }\end{array}$ & Bark & $\mathrm{S}$ \\
\hline Citronella & $\begin{array}{l}\text { Cymbopogon } \\
\text { winterianus }\end{array}$ & $\begin{array}{c}\text { Grass in } \\
\text { flower }\end{array}$ & $\mathrm{S}$ \\
\hline Clary sage & Salvia sclarea & Leaf & $\mathrm{P}$ \\
\hline Clove bud & Syzygium aromaticum & Bud & $S$ \\
\hline $\begin{array}{l}\text { Common } \\
\text { thyme }\end{array}$ & Thymus vulgaris & Flower & $S$ \\
\hline Cypress & Cupressus sempervirens & Branch & $S$ \\
\hline Eucalyptus & Eucalyptus radiate & Leaf & $S$ \\
\hline Frankincense & Boswellia carterii & Sap & $S$ \\
\hline Geranium & Pelargonium roseum & Aerial part & $S$ \\
\hline Ginger & Zingiber officinale & Rhizome & $S$ \\
\hline Grapefruit & Citrus paradisi & Zest & $\mathrm{P}$ \\
\hline Hyssop & Hyssopus officinalis & Leaf & $S$ \\
\hline Juniper & Juniperus communis & Fruit & $S$ \\
\hline Lemon peel & Citrus limon & Zest & $\mathrm{P}$ \\
\hline Lemongrass & Cymbopogon citratus & Plant & $S$ \\
\hline Myrrh & Commiphora myrrha & $\begin{array}{l}\text { Flower \& } \\
\text { wood }\end{array}$ & $\mathrm{S}$ \\
\hline Niaouli & Melaleuca viridiflora & Leaf & $\mathrm{P}$ \\
\hline Patchouli & Pogostemon cablin & Leaf & $S$ \\
\hline Peppermint & Mentha piperita & Leaf & $\mathrm{S}$ \\
\hline Rosemary & Rosmarinus officinalis & $\begin{array}{l}\text { Leaf and } \\
\text { flower }\end{array}$ & $\mathrm{S}$ \\
\hline Sandalwood & $\begin{array}{l}\text { Santalum } \\
\text { austrocaledonicum }\end{array}$ & Wood & $\mathrm{S}$ \\
\hline Scotch pine & Pinus sylvestris & Needle & $S$ \\
\hline Sweet basil & Ocimum basilicum & $\begin{array}{l}\text { Flower and } \\
\text { leaf }\end{array}$ & $\mathrm{S}$ \\
\hline $\begin{array}{l}\text { Sweet } \\
\text { marjoram }\end{array}$ & Origanum majorana & $\begin{array}{l}\text { Flower and } \\
\text { leaf }\end{array}$ & $\mathrm{S}$ \\
\hline Sweet orange & Citrus sinensis & Zest & $\mathrm{P}$ \\
\hline Tea-tree & Melaleuca alternifolia & Leaf & $\mathrm{S}$ \\
\hline $\begin{array}{l}\text { True } \\
\text { lavender }\end{array}$ & Lavandula vera & $\begin{array}{r}\text { Leading } \\
\text { flower }\end{array}$ & $\mathrm{S}$ \\
\hline Ylang-ylang & Cananga odorata & Flower & $S$ \\
\hline
\end{tabular}

$P$ pressure extraction, $S$ steam distillation

mixed with $180 \mathrm{ml}$ distilled water to give a $0.1 \%$ essential oil solution. Triton X-100 $(0.009 \%)$ was added to the diluted solution. A mixture of ethanol $(20 \mathrm{ml})$, Triton 
$\mathrm{X}-100(0.009 \%)$, and distilled water $(180 \mathrm{ml})$ was used as a negative control.

A leaf-dip method was used for bioassays with the 34 essential oils. Each experimental unit was kept in a plastic Petri dish $(60 \times 15 \mathrm{~mm})$ and consisted of a treated kidney bean leaf disk (30-mm diameter) placed on cotton pads that had been soaked in distilled water. Thirty adult females were placed on the lower surface of a bean leaf disk with a fine brush. The mites were allowed to acclimate for $30 \mathrm{~min}$. The bean leaf disks were dipped individually in the $0.1 \%$ essential oil treatment for $5 \mathrm{~s}$ and dried at ambient temperature in the laboratory for $20 \mathrm{~min}$, then placed upside down on the cotton pad in the Petri dish. Petri dishes were maintained at $24 \pm 2{ }^{\circ} \mathrm{C}, 40-80 \% \mathrm{RH}$, and 16L:8D. Numbers of live and dead TSSM adults were counted at $24 \mathrm{~h}$ post-treatment. TSSM adults were considered dead if no movement was apparent after probing with the tip of a fine brush. The number of TSSM eggs was counted under a dissecting microscope (Stemi 2000, Carl Zeiss, Germany). Each treatment was replicated three times. Given that the major compounds in sandalwood oil were identified as $\alpha$ and $\beta$-santalol, santalol (a mixture of $\alpha$ - and $\beta$-santalol) was tested for its acaricidal activity against $T$. urticae using the same leaf-dip method described above.

\section{Phytotoxicity test}

The phytotoxicity of sandalwood oil was tested on rose shoots (Rosa hybrida, L. cv. "Peace One") using a $0.1 \%$ solution (sandalwood oil $200 \mu \mathrm{l}+$ ethanol $20 \mathrm{ml}+$ distilled water $180 \mathrm{ml}$, and Triton X-100). Rose shoots bearing flowers, leaves, and buds were obtained from the Department of Horticulture, Gyeongsang National University, Korea. The sandalwood oil solution was sprayed on rose shoots in a triangle flask $(500 \mathrm{ml})$ using a $500 \mathrm{ml}$ hand sprayer until run off. Each rose shoot was sprayed with approximately $30 \mathrm{ml}$ of solution. Control rose shoots were sprayed with $10 \%$ ethanol solution (ethanol $20 \mathrm{ml}+$ distilled water $180 \mathrm{ml}+$ Triton X-100). A negative control was also included in which rose shoots were not sprayed. Rose shoots were then arranged in a $500 \mathrm{ml}$ triangle flask filled with tap water in a laboratory maintained at $26 \pm 2{ }^{\circ} \mathrm{C}, 16 \mathrm{~L}: 8 \mathrm{D}$. Phytotoxicity was evaluated $24 \mathrm{~h}$ after treatment and categorized from grade 0 (no damage) to grade 4 (brown spots on whole leaves) (Miresmailli and Isman 2006). Each treatment was replicated three times.

Chemical analysis of sandalwood oil

As sandalwood oil demonstrated the highest acaricidal activity against $T$. urticae adults, it was subjected to gas chromatography/mass spectrometry (GC-MS) to identify major constituents in the oil. This was conducted using a
QP2010 plus GC-MS, (Shimadzu, Japan) using a $30 \mathrm{~m} \times 0.25 \mathrm{~mm}$ i.d. $\times 0.25 \mu \mathrm{m}$ DB-WAX capillary column ( $\mathrm{J} \& \mathrm{~W}$ Scientific Co., USA). The temperature program started at $40^{\circ} \mathrm{C}$ and increased to $200^{\circ} \mathrm{C}$ at $2^{\circ} \mathrm{C} / \mathrm{min}$. Split injection (1:10 ratio) was performed with $1 \mu \mathrm{l}$ sample volume using an auto-sampler. The temperature was $220^{\circ} \mathrm{C}$ at the injection site, and helium was used as a carrier gas at a flow rate of $1 \mathrm{ml} / \mathrm{min}$. The mass detector was fitted with an Electron Ionization source operated at $70 \mathrm{eV}$ with a source temperature of $180^{\circ} \mathrm{C}$, and mass spectra were recorded in the range of $\mathrm{m} / \mathrm{z} 38-300$ at 1 scan $/ 0.75 \mathrm{~s}$. Essential oils diluted in diethyl ether $(0.5 \% \mathrm{v} / \mathrm{v})$ were used for chemical analysis. Identification of compounds in sandalwood oil was based on the mass spectral information in a mass spectra library (Wiley Registry of Mass Spectra Data, 2000), and peaks of the samples were further confirmed by comparison with mass spectra of standards.

Statistical analysis

Corrected mortality (\%) of adult female transformed by Abbott's formula and the number of eggs laid by adult females were subjected to analysis of variance (ANOVA), and the differences among treatment means were compared using a Tukey's studentized range test $(P<0.05)$. All statistical analyses were conducted using SAS (SAS Institute 1999)

\section{Results}

Acaricidal activity of essential oils

Mortality due to treatment with 34 essential oils and the number of eggs laid by the females treated with those oils did not differ significantly $(P<0.05)$ from the control $(2.9 \%)$, although it approached significance $(P=0.0588)$ (Table 2). However, the mortality caused by treatment with sandalwood oil $(89.4 \%)$ was highest, followed by that from common thyme oil (62.8\%). In addition, the total number of eggs laid was lowest on the leaf disk dipped in the sandalwood oil solution. The number of eggs per live adult did not differ between oil treatments.

Because sandalwood and common thyme oil produced higher TSSM mortality compared with other oils, the acaricidal activities of the two oils were retested. Sandalwood oil was significantly more effective than common thyme oil and the two controls (0.0 and $1.1 \%)$ (Table 3). Mortality of the sandalwood oil treatment was higher and total number of eggs of the treatment was lower than that of common thyme oil. Mortality and the total number of eggs laid by TSSM adults treated with sandalwood oil in the 2nd trial were similar to those of 
Table 2 Acaricidal activity of essential oils against Tetranychus urticae adult females at $0.1 \%$ concentration $24 \mathrm{~h}$ after treatment (Mean \pm SD)

\begin{tabular}{|c|c|c|c|}
\hline Essential oils & Corrected mortality (\%) & Total no. of eggs & No. of eggs per live adult \\
\hline Bergamot & $11.0 \pm 6.0$ & $225.0 \pm 24.1$ & $10.2 \pm 0.9$ \\
\hline Bitter orange & $21.4 \pm 21.5$ & $205.3 \pm 58.1$ & $10.1 \pm 0.8$ \\
\hline Black pepper & $22.8 \pm 20.0$ & $239.0 \pm 76.7$ & $12.0 \pm 1.2$ \\
\hline Blue gum & $19.7 \pm 22.5$ & $209.7 \pm 50.9$ & $9.6 \pm 1.9$ \\
\hline Cajeput tree & $23.5 \pm 11.4$ & $201.3 \pm 13.3$ & $9.5 \pm 1.4$ \\
\hline Cedar wood & $12.4 \pm 6.7$ & $224.0 \pm 63.0$ & $9.5 \pm 3.2$ \\
\hline Cinnamon & $23.6 \pm 20.6$ & $211.0 \pm 51.6$ & $10.8 \pm 1.6$ \\
\hline Citronella & $27.6 \pm 20.7$ & $192.3 \pm 48.0$ & $8.6 \pm 1.7$ \\
\hline Clary sage & $7.1 \pm 0.2$ & $214.7 \pm 77.5$ & $8.7 \pm 3.2$ \\
\hline Clove bud & $41.3 \pm 36.3$ & $174.3 \pm 118.3$ & $10.2 \pm 0.9$ \\
\hline Common thyme & $62.2 \pm 42.0$ & $131.7 \pm 151.4$ & $17.3 \pm 9.4$ \\
\hline Cypress & $28.9 \pm 18.4$ & $198.7 \pm 55.5$ & $10.7 \pm 1.5$ \\
\hline Eucalyptus & $27.9 \pm 21.7$ & $201.0 \pm 36.4$ & $9.9 \pm 2.2$ \\
\hline Frankincense & $24.8 \pm 27.7$ & $219.0 \pm 98.3$ & $10.3 \pm 2.4$ \\
\hline Geranium & $30.0 \pm 15.7$ & $193.3 \pm 13.1$ & $10.6 \pm 3.1$ \\
\hline Ginger & $11.9 \pm 13.0$ & $242.0 \pm 41.1$ & $10.2 \pm 0.2$ \\
\hline Grapefruit & $30.6 \pm 35.2$ & $188.7 \pm 70.8$ & $11.7 \pm 3.6$ \\
\hline Hyssop & $28.1 \pm 22.3$ & $196.7 \pm 55.8$ & $9.5 \pm 1.7$ \\
\hline Juniper & $42.6 \pm 21.8$ & $128.0 \pm 82.0$ & $7.9 \pm 3.4$ \\
\hline Lemon peel & $34.9 \pm 37.9$ & $129.3 \pm 68.7$ & $8.5 \pm 1.7$ \\
\hline Lemongrass & $17.8 \pm 9.5$ & $210.3 \pm 48.4$ & $10.0 \pm 4.0$ \\
\hline Myrrh & $22.8 \pm 17.8$ & $189.7 \pm 70.2$ & $8.9 \pm 2.0$ \\
\hline Niaouli & $26.8 \pm 30.7$ & $213.0 \pm 85.0$ & $10.8 \pm 0.4$ \\
\hline Patchouli & $20.3 \pm 20.4$ & $243.3 \pm 86.0$ & $10.9 \pm 1.6$ \\
\hline Peppermint & $23.7 \pm 18.2$ & $215.7 \pm 52.3$ & $10.5 \pm 1.8$ \\
\hline Rosemary & $11.7 \pm 22.0$ & $212.3 \pm 33.3$ & $9.3 \pm 2.3$ \\
\hline Sandalwood & $89.2 \pm 8.5$ & $28.0 \pm 10.0$ & $13.2 \pm 5.2$ \\
\hline Scotch pine & $50.4 \pm 18.5$ & $159.7 \pm 53.5$ & $14.6 \pm 11.1$ \\
\hline Sweet basil & $21.0 \pm 17.9$ & $209.3 \pm 62.4$ & $10.5 \pm 1.9$ \\
\hline Sweet marjoram & $7.1 \pm 0.2$ & $236.7 \pm 18.6$ & $9.5 \pm 0.5$ \\
\hline Sweet orange & $45.6 \pm 37.4$ & $123.0 \pm 51.9$ & $9.4 \pm 2.9$ \\
\hline Tea-tree & $28.6 \pm 33.5$ & $142.7 \pm 70.5$ & $7.7 \pm 2.3$ \\
\hline True lavender & $26.1 \pm 21.2$ & $226.3 \pm 85.7$ & $11.0 \pm 1.3$ \\
\hline Ylang-Ylang & $24.2 \pm 14.9$ & $221.7 \pm 111.3$ & $10.2 \pm 4.2$ \\
\hline $\mathrm{EtOH}+$ Triton-X + water & $10.9 \pm 4.4$ & $227.0 \pm 27.1$ & $10.8 \pm 1.3$ \\
\hline Control & 0.0 & $323.7 \pm 52.0$ & $13.1 \pm 3.6$ \\
\hline Statistics & $F=1.46$ & $F=1.56$ & $F=0.89$ \\
\hline at $d f=35,72$ & $P=0.0588$ & $P=0.0576$ & $P=0.6423$ \\
\hline
\end{tabular}

the 1 st trial. However, the effectiveness of common thyme oil decreased dramatically between the first and second experiments and did not cause any substantial mortality relative to the two controls.

\section{Phytotoxicity}

There was no evidence of phytotoxicity found on the flowers, foliage, buds, or stems of roses in response to the sandalwood oil treatment.
Chemical composition of sandalwood oil

Table 4 shows the GC-MS analysis of sandalwood oil. The GC-MS analysis revealed that the main constituents identified from sandalwood oil were $\alpha$-santalol (45.8\%), $\beta$-santalol (20.6\%), $\beta$-sinensal (9.4\%), and epi- $\beta$-santalol (3.3\%).

Acaricidal activity of santalol

The effect of santalol against TSSM adult females is shown in Table 5. Mortality caused by dipping the leaf disks and 
Table 3 Acaricidal activity of selected essential oils against Tetranychus urticae adult females at $0.1 \%$ concentration $24 \mathrm{~h}$ after treatment $($ Mean $\pm \mathrm{SD})$

\begin{tabular}{llll}
\hline Treatment & Corrected mortality $(\%)$ & Total no. of eggs & No. of eggs per live adult \\
\hline Sandalwood & $87.0 \pm 3.2 \mathrm{a}^{\mathrm{a}}$ & $33.3 \pm 15.0 \mathrm{~b}$ & $9.7 \pm 2.8 \mathrm{a}$ \\
Common thyme & $4.5 \pm 5.3 \mathrm{~b}$ & $228.0 \pm 62.5 \mathrm{ab}$ & $10.8 \pm 1.0 \mathrm{a}$ \\
EtOH + Triton-X + Water & $0.0 \pm 0.0 \mathrm{~b}$ & $242.7 \pm 76.0 \mathrm{a}$ & $8.6 \pm 2.4 \mathrm{a}$ \\
Control & $0.0 \mathrm{~b}$ & $311.3 \pm 68.2 \mathrm{a}$ & $10.6 \pm 2.1 \mathrm{a}$ \\
Statistics & $F=109.62$ & $F=11.74$ & $F=0.61$ \\
at $d f=3,8$ & $P \leq 0.0001$ & $P=0.0027$ & $P=0.6249$ \\
\hline
\end{tabular}

a Values followed by the same letter within a column are not significantly different at $P=0.05$ (Tukey's HSD test)

Table 4 Chemical composition of sandalwood oil

\begin{tabular}{|c|c|c|c|c|c|}
\hline \multirow[t]{2}{*}{ Compound } & \multirow[t]{2}{*}{ Mass spectral data of sandalwood oil ${ }^{\mathrm{a}}$} & \multicolumn{2}{|c|}{ Retention time (min) } & \multicolumn{2}{|c|}{ Composition $(\%)^{\mathrm{b}}$} \\
\hline & & Sandalwood & $\begin{array}{l}\text { Authentic } \\
\text { sample }\end{array}$ & $\begin{array}{l}\text { Sandalwood } \\
\text { oil }\end{array}$ & $\begin{array}{l}\text { Authentic } \\
\text { sample }\end{array}$ \\
\hline$\alpha$-santalol & $220,202,187,147,133,122,107,94,79,77,67,55,43$ & 44.172 & 44.141 & 45.8 & 51.0 \\
\hline$\beta$-sinensal & $220,202,147,93,79,67,55$ & 44.624 & 44.609 & 9.4 & 9.9 \\
\hline Epi- $\beta$-santalol & $202,187,161,134,122,107,94,79,77,67,55$ & 46.619 & 46.597 & 3.3 & 3.1 \\
\hline$\beta$-santalol & $220,202,189,161,147,133,122,107,94,79,77,67,55,43$ & 47.162 & 47.148 & 20.6 & 22.9 \\
\hline
\end{tabular}

${ }^{a}$ Major fragments (EI mode)

${ }^{\mathrm{b}}$ Data based on chromatogram peak areas

Table 5 Acaricidal activities of the main constituents of sandalwood oil against Tetranychus urticae adult females at $0.1 \%$ concentration $24 \mathrm{~h}$ after treatment (Mean $\pm \mathrm{SD})$

\begin{tabular}{llll}
\hline Treatment & Corrected mortality $(\%)$ & Total no. of eggs & No. of eggs per live adult \\
\hline Santalol $^{\mathrm{a}}$ & $85.5 \pm 2.9 \mathrm{a}^{\mathrm{b}}$ & $18.3 \pm 3.5 \mathrm{c}$ & $4.6 \pm 0.3 \mathrm{c}$ \\
EtOH + Triton-X + Water & $0.0 \pm 0.0 \mathrm{~b}$ & $213.3 \pm 10.1 \mathrm{~b}$ & $8.7 \pm 0.6 \mathrm{~b}$ \\
Control & $0.0 \mathrm{~b}$ & $348.0 \pm 16.1 \mathrm{a}$ & $14.2 \pm 1.0 \mathrm{a}$ \\
Statistics & $F=9121.2$ & $F=289.38$ & $F=149.35$ \\
at $d f=3,8$ & $P \leq 0.0001$ & $P \leq 0.0001$ & $P \leq 0.0001$ \\
\hline
\end{tabular}

${ }^{a}$ Santalol is a mixture of $\alpha$ - and $\beta$-santalol in the ratio of $51: 23 \%$

b Values followed by the same letter within a column are not significantly different at $P=0.05$ (Tukey's HSD test)

spider mites in the santalol solution was significantly higher than those of the two controls $(0.0 \%)$. The total number of eggs and the number of eggs laid by live females were significantly reduced by the santalol treatment.

\section{Discussion}

Much effort has been focused on plant essential oils as potential sources of insect control agents. Sandalwood (Santalum album L.) is one of the most valuable trees in the world (Fox 2000). It occurs naturally or may be cultivated in India (FAO 1995). The essential oil derived from sandalwood is typically used as a flavor component in many food products, including alcoholic and non-alcoholic beverages (Burdock and Carabin 2008).

The sandalwood oil tested in this study $(0.1 \%$ solution $)$ caused significant mortality $(87.2 \%)$ in TSSM adults and significantly decreased the total number of eggs, proportionally according to the number of live versus dead females (Table 3). Lethality of sandalwood oil of the 2 nd trial was similar to that of the 1 st one. However, the lethality of common thyme oil in the 1st trial was much higher than in the 2 nd one, possibly because of high variation among replications in the 1st trial (Tables 2, 3). Even though Miresmailli and Isman (2006) found that rosemary oil was toxic to TSSM with an $\mathrm{LC}_{50}$ of $13 \mathrm{ml} / \mathrm{l}(1.3 \%$ solution), our rosemary oil was not effective against TSSM 
in this study. This result suggests that the essential oil of sandalwood trees may be used for effective management of TSSM. There are some other reports that plant-derived essential oils are effective to spider mites. Essential oils extracted from Cuminum cyminum L. and Origanum syriacum var bevanii (Holmes) Ietswaart have been demonstrated to be effective as greenhouse fumigants for the control of the carmine spider mite and the melon/cotton aphid (Tuni and Sahinkaya 1998). Essential oils obtained from some other aromatic plants showed toxic effects on insects and mites (Choi et al. 2004; Tripathi et al. 2000).

GC-MS analysis revealed that sandalwood oil primarily consisted of $\alpha$-santalol (45.8\%) and $\beta$-santalol (20.6\%) (Table 4). The composition of $\alpha$ - and $\beta$-santalol in our sample oil was not different from the analyses of other researchers who reported that $\alpha$-santalol $(\sim 46 \%)$ was more abundant than $\beta$-santalol $(\sim 20 \%)$ in sandalwood oil (Anonis 1998). Previous research has also shown that sandalwood oil consists almost exclusively of closely related sesquiterpenoids, in addition to the main constituents of $\alpha$-santalol $(\geq 43 \%)$ and $\beta$-santalol ( $\geq 18 \%)$, supporting the results observed here (Burdock and Carabin 2008).

The santalol solution demonstrated significant toxicity at $0.1 \%$ and significantly decreased the number of eggs laid by live TSSM adults (Table 5). Some previous studies reported that the acaricidal and/or insecticidal effects of plant essential oils were related to their chemical compositions (Pascual-Villalobus and Ballesta-Acosta 2003). The major constituents of essential oils have been effective in controlling various pests including TSSM. For example, thymol and carvacrol, the major compounds in thyme (Thymus vulgaris L.) and oregano (Origanum vulgare L.) essential oils, have been identified as potential insect antifeedants and oviposition deterrents against TSSM (ElGengaihi et al. 1996) and tobacco cut-worm (Spodoptera litura Fabricius) (Isman et al. 2001). Several laboratory studies have described the acaricidal activity of essential oils and their major constituents (Basta and Spooner-Hart 2002; Cetin et al. 2009). However, no research has been reported on the effect of sandalwood oil and its major constituents against TSSM.

Jiang et al. (2009) indicates that the inactive constituents from Litsea pungens Hemsl. and L. cubeba (Lour.) Pers. (Lauraceae) have some synergistic effect on the active constituents and that, although not active individually, their presence is necessary to achieve full toxicity by contact against third-instar Trichoplusia ni larvae (Lepidoptera: Noctuidae). Also, Miresmailli et al. (2006) reported the acaricidal activity of Rosmarinus officinalis L. essential oil and blends of selected constituents indicated a synergistic effect among the active and inactive constituents against TSSM. In this study, we did not test the synergistic effects on TSSM of minor constituents in sandalwood oil which will possibly be valuable to be studied to get sufficient control efficacy.

Although plant-derived essential oils may be active against certain pests, one concern associated with their use is the possibility of plant injury or phytotoxicity (Arnason et al. 1993). In fact, many plant-derived essential oils are phytotoxic to vegetables and herbaceous and foliar plant material (Isman 1999). However, the extent of plant injury may be dependent on numerous factors, including the concentration of the compound, the rate at which it is applied, plant type, and which plant parts (e.g., leaves or flowers) are exposed during spray applications (Cloyd et al. 2009). In our test, sandalwood oil was not phytotoxic to flowers, foliage, buds, or stems of rose plant at a concentration of $0.1 \%$.

In conclusion, this is the first study demonstrating that sandalwood oil and its constituents have acaricidal activities to TSSM, and decreased the number of eggs on treated leaves. Thus, sandalwood oil and santalol can likely be used for the sustainable management of TSSM on roses and possibly for susceptible greenhouse crops. However, this study only screened the essential oil and its constituents in the laboratory. Further studies are needed to further evaluate the acaricidal effects of the santalol in the field. It would also be valuable to test the efficacy of santalol against small and soft-bodied insect pests such as the western flower thrips, Frankliniella occidentalis Pergande, the cotton aphid, Aphis gossypii Glover, and the green peach aphid, Myzus persicae Sulzer, which are also major pests in many greenhouse crops.

Acknowledgment We thank Dr. Cristina Machial (Faculty of Land and Food Systems, University of British Columbia, Canada) for helpful comments on the manuscript. Hyun Sik Roh was supported by a grant from the BK21 Program, the Ministry of Education, Science and Technology, Korea.

Open Access This article is distributed under the terms of the Creative Commons Attribution Noncommercial License which permits any noncommercial use, distribution, and reproduction in any medium, provided the original author(s) and source are credited.

\section{References}

Anonis DP (1998) Sandalwood and sandalwood compounds. Perfumer Flavorist 23:19-24

Antonious GF, Meyer JE, Snyder JC (2006) Toxicity and repellency of hot pepper extracts to spider mite, Tetranychus urticae Koch. J Environ Sci Health B 41:1383-1391

Arnason JT, MacKinnon S, Durst A, Philogene BJR, Hasbun C, Sanchez P, Poveda L, San Roman L, Isman MB, Satasook C (1993) Phytochemical potential of tropical plants. In: Downum KR, Romeo JT, Stafford HA (eds) Insecticides in tropical plants with non-neurotoxic modes of action, Chap. 5. Plenum, New York, pp 107-131 
Badawy MEI, EI-Arami SAA, Abdelgaleil SAM (2010) Acaricidal and quantitative structure activity relationship of monoterpenes against the two-spotted spider mite, Tetranychus urticae. Exp Appl Acarol 52:261-274

Basta A, Spooner-Hart RN (2002) Efficacy of an extract of Dorrigo pepper against two-spotted mite and greenhouse thrips. In: Beattie GAC, Watson DM, Stevens ML, Rae DJ, Spooner-Hart RN (eds) Spray oils beyond 2000, 25-29 October 1999. University of Western Sydney, Australia, pp 471-476

Burdock GA, Carabin IG (2008) Safety assessment of sandalwood oil (Santalum album L.). Food Chem Toxicol 46:421-432

Cetin H, Cilek JE, Aydin L, Yanikoglu A (2009) Acaricidal effects of the essential oil of Origanum minutiflorum (Lamiaceae) against Rhipicephalus turanicus (Acari: Ixodidae). Vet Parasitol 160: 359-361

Chermenskaya TD, Stepanycheva EA, Shchenikova AV, Chakaeva ASh (2010) Insectoacaricidal and deterrent activities of extracts of Kyrgyzstan plants against three agricultural pests. Ind Crops Prod 32:157-163

Cho JR, Kim YJ, Ahn YJ, Yoo JK, Lee JO (1995) Monitoring of acaricide resistance in field-collected populations of Tetranychus urticae (Acari: Tetranychidae) in Korea. Korean J Appl Entomol 34:40-45

Choi WL, Lee SG, Park HM, Ahn YJ (2004) Toxicity of plant essential oils to Tetranychus urticae (Acari: Tetranychidae) and Phytoseiulus persimilis (Acari: Phytoseiidae). J Econ Entomol 97:553-558

Cloyd RA, Galle CL, Keith SR, Kalscheur NA, Kemp KE (2009) Effect of commercially available plant derived essential oil products on arthropod pest. J Econ Entomol 102(4):1567-1579

El-Gengaihi DE, Amer SAA, Mohamed SM (1996) Biological activity of thyme oil and thymol against Tetranychus urticae Koch. Anz Schädlingskd 69:157-159

FAO (1995) Flavours and fragrances of plant origin. Sandalwood oil, Chapter. Food and Agriculture Organization of the United Nation. http://www.fao.org/docrep/V5350E/V5350e08.htm

Fox JE (2000) Sandalwood: the royal tree. Biogist Lond 47:31-34

Hussein H, Abou-Elelia M, Amer SAA, Momen FM (2006) Repellency and toxicity of extracts from Capparis aegyptia L to Tetranychus urticae Koch. (Acari:Tetranychidae). Acta Phytopathol Entomol Hung 41:331-340

Isman MB (1999) Pesticides based on plant essential oils. Pestic Outlook 10:68-72

Isman MB (2001) Pesticides based on plant essential oils for management of plant pests and disease. International Symposium on Development of Natural Pesticides from Forest Resources. Korea Forest Research Institute, Seoul, pp 1-9

Isman MB, Wan AJ, Passreiter CM (2001) Insecticidal activity of essential oils to the tobacco cutworm, Spodoptera litura. Fitoterapia 72:65-78
Jiang Z, Akhtar Y, Bradbury R, Zhang X, Isman MB (2009) Comparative toxicity of essential oils of Litsea pungens and Litsea cubeba and blends of their major constituents against the cabbage looper, Trichoplusia ni. J Agric Food Chem 57: 4833-4837

Kumral NA, Cobanoglu S, Yalcin C (2010) Acaricidal, repellent and oviposition deterrent activities of Datura stramonium L. against adult Tetranychus urticae (Koch). J Pest Sci 83:173-180

Lee SY, Yoo JS, Moon SJ, Lee SG, Kim CS, Shin SC, Kim GH (2003a) Fumigant and repellency effects of terpenes against the two spotted spider mite, Tetranychus urticae (Acari: Tetranychidae). Korean J Appl Entomol 42:249-255

Lee YS, Song MH, Ahn KS, Lee KY, Kim JW, Shin SC, Kim GH (2003b) Monitoring of acaricide resistance in two spotted spider mite (Tetranychus urticae) populations from rose green houses in Korea. J Asia-Pac Entomol 5:237-240

Miresmailli S, Isman MB (2006) Efficacy and persistence of rosemary oil as an acaricide against two spotted Spider mite (Acari: Tetranychidae) on greenhouse tomato. J Econ Entomol 99:2015-2023

Miresmailli S, Bradbury R, Isman MB (2006) Comparative toxicity of Rosmarinus officinalis $\mathrm{L}$ essential oil and blends of its major constituents against Tetranychus urticae Koch (Acari: Tetranychidae) on two different host plants. Pest Manag Sci 62:366-371

Pascual-Villalobus MJ, Ballesta-Acosta MC (2003) Chemical variation in an Ocimum basilicum germplasm collection and activity of the essential oil on Collosobruchus maculatus. Biochem Syst Ecol 31:673-679

Rasikari HL, Leach DN, Waterman PG, Spooner-Hart RN, Basta AH, Banbury LK, Forster PI (2005) Acaricidal and cytotoxic activities of extracts from selected genera of Australian Lamiaceae. J Econ Entomol 98:1259-1266

SAS Institute (1999) STATVIEW. SAS Institute, Inc., Cary, NC

Song C, Kim GH, Ahn SJ, Park NJ, Cho KY (1995) Acaricide susceptibilities of the field collected populations of two-spotted spider mite, Tetranychus urticae (Acari: Tetranych idea) from apple orchards. Korean J Appl Entomol 34:328-333

Stavrinides MC, Hadjistylli M (2009) Two-spotted spider mite in Cyprus: ineffective acaricides, causes and considerations. J Pest Sci 82:123-128

Takafuji A, Ozawa A, Nemoto H, Gotoh T (2000) Spider mites of Japan: their biology and control. Exp Appl Acarol 24:319-335

Tripathi AK, Prajapati V, Aggarwal KK, Khanuja SPS, Kumar S (2000) Repellency and toxicity of oil from Artemisia апnиа to certain stored product beetles. J Econ Entomol 93(1):43-47

Tuni I, Sahinkaya S (1998) Sensitivity of two greenhouse pests to vapors of essential oils. Entomol Exp Appl 86:312-324

Van Pottelberge S, Van Leeuwen T, Khajehali J, Tirry L (2009) Genetic and biochemical analysis of a laboratory-selected spirodiclofen-resistant strain of Tetranychus urticae Koch (Acari: Tetranychidae). Pest Manag Sci 65:358-366 